\title{
Responses of small mammals to clear-cutting in temperate and boreal forests of Europe: a meta-analysis and review
}

\author{
Bogdziewicz Michał $\cdot$ Zwolak Rafał
}

Received: 3 April 2013/Revised: 6 July 2013/Accepted: 5 August 2013/Published online: 17 August 2013

(C) The Author(s) 2013. This article is published with open access at Springerlink.com

\begin{abstract}
We analyzed the responses of small mammals to clear-cutting in temperate and boreal forests in Europe. We conducted a meta-analysis of published research on most often studied small mammal species (the striped field mouse, the yellow-necked mouse, the wood mouse, the field vole, the common vole, the bank vole, the Eurasian harvest mouse, the common shrew and the Eurasian pygmy shrew), comparing their abundance on clear-cuts and in unharvested stands. For four other species (the gray-sided vole, the Siberian flying squirrel, the Eurasian red squirrel and the hazel dormouse), we provide a qualitative review of their responses to forest harvest. Results of the metaanalysis suggest that common species of small mammals usually increase in abundance after clear-cutting or are unaffected by this disturbance. As an exception, the yellow-necked mouse declines after clear-cutting in boreal but not in temperate forest. The qualitative review suggests that the responses of more specialized (e.g., arboreal) species to forest harvest are more varied than the responses of generalist species included in the meta-analysis. For some species of small mammals (e.g., the Siberian flying squirrel), habitat loss resulting from forest harvest is a major threat.
\end{abstract}

Keywords European forests - Forest management . Logging $\cdot$ Rodents $\cdot$ Shrews

Communicated by Jörg Müller.

B. Michał $(\bowtie) \cdot$ Z. Rafał

Department of Systematic Zoology, Institute of Environmental

Biology, Adam Mickiewicz University, Umultowska 89,

61-614 Poznan, Poland

e-mail: michalbogdziewicz@gmail.com

\section{Introduction}

One of the main goals of sustainable modern forestry is maintaining biodiversity in conjunction with ensuring economic services of forests (Bengtsson et al. 2000). To achieve this objective, we need to develop an adequate scientific knowledge on the influence of management practices on forest ecosystems (Simberloff 1999). This will permit the development of effective conservation policies, based on solid scientific evidences (Sutherland et al. 2004). Modern forestry has considerably transformed forests both on the stand and landscape level, and original patterns of those remained only in some remote, mainly mountainous areas (Hansson 1992a). In fact, there are almost no intact forests in Europe (Hannah et al. 1995). For economical reasons, forest harvest is often conducted in the form of clear-cutting, especially in northern parts of Europe (Keenan and Kimmins 1993; Kuuluvainen 2009). Consequently, clear-cutting has replaced fires and wind-throws as the main disturbance in northern part of the continent (Östlund et al. 1997; Kuuluvainen 2009). However, its environmental impact is highly controversial (Keenan and Kimmins 1993; Simberloff 2001; Angelstam and Kuuluvainen 2004; Kuuluvainen 2009). Therefore, there is a need for gathering reliable scientific knowledge on the influence of clear-cutting on different aspects of forest ecosystems.

Small mammals (rodents and shrews) are mostly common and generalist species that play important role in many ecosystems worldwide, including European forests. Small mammals are core components of forest food webs. They can influence tree recruitment through selective foraging on seeds (García et al. 2005; Zwolak et al. 2010) and seedlings (Ostfeld et al. 1997; Gómez et al. 2003). On the other hand, many species of rodents promote forest regeneration by dispersing seeds and caching them in safe 
sites (den Ouden et al. 2005; Zwolak and Crone 2012). Small mammals also eat and disperse spores of mycorrhizal fungi, thus enhancing functioning of forest trees (Schickmann et al. 2012). Rodents and shrews are important consumers of invertebrates (Drożdż 1966; Churchfield and Rychlik 2006) and may control insect populations (Jones et al. 1998). Small mammals are a crucial part of the diet of numerous species of predators and birds of prey (Jędrzejewska and Jędrzejewski 1998).In addition to their strong trophic interactions, forest small mammals represent important reservoirs of zoonotic pathogens, such as Borellia (a cause of Lyme disease) and Hantavirus, a pathogen that can cause nephropathia epidemica (NE) in humans (Heyman et al. 2009). There are several studies that summarize the growing body of literature on the influence of forest management in Europe on different taxa of wildlife (e.g., Paillet et al. 2010; Prieto-Benítez and Méndez 2011). However, to the best of our knowledge, there is no such work for small mammals. While in Northern America, there were several reviews on effects of forest management on this important group (Kirkland 1990; Fisher and Wilkinson 2005; Zwolak 2009), similar syntheses on European small mammals are still lacking. In this paper, we aimed to summarize the results of studies investigating the influence of forest harvest on small mammal abundance on the stand level. We focus mainly on clear-cutting because it is one of the most common methods of forest harvest and almost all studies on responses of small mammals to logging in Europe concern this harvest method. For several species of small mammals, relatively large number of published studies of their responses to clear-cutting enabled us to use a meta-analytic approach (Fernandez-Duque and Valeggia 1994). This approach has several advantages over narrative reviews. Most importantly, it is less subjective than traditional reviews and allows improved control of type II statistical error (Arnqvist and Wooster 1995). In a few other cases where we were unable to conduct quantitative analysis, we provided a brief synthesis of the results of published studies conducted both on stand and landscape level.

\section{Materials and methods}

\section{Data collection}

We searched the Web of Science and Google Scholar online databases for peer-reviewed studies that examined the effects of forest harvest on small mammal abundance. To identify focal publications, we used the following search words: (logging OR clear-cut* OR harvest) AND (rodent OR "small mammal*" OR mice) AND forest. We have also conducted separate search for each species using the Latin and English name of each species instead of phrase "small mammal*" OR mice (e.g., "common shrew" OR "Sorex araneus"). We selected only studies that were conducted in Europe. The lists of references from relevant articles were used to find studies that were not found in the first search. We also screened studies that cited focal publications to ensure that we did not miss any article of interest. This searching process was repeated until no further publications could be retrieved. The search was conducted in November 2012.

For the meta-analysis, we selected studies that reported small mammal abundances both in clear-cuts and in unharvested or mature forest. We included only studies conducted up to 20 years post-harvest because studies that reported small mammal abundances on older clear-cuts too rare to provide meaningful inference (5 studies and only 13 out of 169 extracted data points; see Results). We excluded studies that reported data only from harvested sites and studies that did not provide data sufficient to compare abundances in clear-cuts and unharvested stands. To avoid including data points based on accidental captures, we used only studies where at least 10 individuals were captured. Otherwise, we did not use any selection criteria based on quality features of studies because such procedures can lead to potential bias (Englund et al. 1999). If several articles reported the same data, we chose one that provided the most inclusive version. In cases where a single study provided data on abundance of small mammals on several clear-cuts of different age or in different forest types, they were used as independent data points. Otherwise, data were averaged (e.g., several replicates in the same forest type). We did not include studies where abundance of related species was pooled because species within the same genus might react differently to forest disturbance (Sidorovich et al. 2008). Two studies reported data on abundance of small mammals on clearings caused by air pollution (Čepelka et al. 2011; Bryja et al. 2002). As these clearings were the result of cutting and removing trees, they were very similar in structure to commercial clear-cuts (J. Bryja, personal communication) and we decided to include them into our analysis.

\section{Calculation of effect sizes}

As evaluating small mammal abundance requires large trapping effort, most of the analyzed studies were not replicated or the number of replicates was too small to calculate variance. Therefore, we were not able to calculate classical effect sizes based on variance (e.g., Gurevitch et al. 1992). Instead, we used the relative abundance index (RAI) developed by Vanderwel et al. (2007): 


$$
\mathrm{RAI}=\frac{N_{\text {clear-cut }}-N_{\text {forest }}}{N_{\text {clear-cut }}+N_{\text {forest }}}
$$

where $N_{\text {clear-cut }}$ is the abundance of focal species in clearcut and $N_{\text {forest }}$ is the abundance of focal species in undisturbed forest. If there was a difference in trapping effort between clear-cut and unharvested stands, we standardized the abundance, e.g., by calculating the number of captures per 100 trap nights. RAI ranges from -1 (when a given species was found only in undisturbed forest) to +1 (when it was found only on clear-cuts) and equals zero when a given species is equally abundant in clear-cuts and undisturbed forest. If a study reported data on abundance for each year of the study separately, we averaged abundance for each species across years.

\section{Publication bias}

Publication bias in meta-analysis arises when studies with significant results are more likely to be published than those with non-significant results (Murtaugh 2002). We examined funnel plots and conducted linear regression of effect size (RAI) on sample size (the number of captured individuals), as recommended by Egger et al. 1997. We found no relationship between RAI and sample size, and thus, there was no evidence of the publication bias in our set of studies.

Another type of bias can arise from lack of independence among data points if proportionally large number of observations comes from few studies (Gurevitch and Hedges 1999). It was not the case in our analysis because there were no studies providing more than $5 \%$ of data points for a given species (mean $=2.1$ data points, $\mathrm{SD}=1.4)$.

\section{Statistical methods}

We analyzed species-specific responses of small mammals to clear-cutting using generalized liner models with RAI as the response variable and small mammal species, vegetation zone (boreal or temperate forest) and interaction between these two as explanatory variables. We also explored models that included age and area of clear-cuts, but these variables turned out non-significant (unpublished analyses). Similarly, we also analyzed the data using general mixed models that included correlated random effect of small mammal species over study. However, inclusion of the random effect had negligible influence on results, and thus, we reported results of the less complicated statistical method (as recommended by Zuur et al. 2009). We used model validation graphs and confirmed the assumption of homogeneity (fitted values versus residuals) and normality (QQ plots) in our model. All the statistics were computed in $\mathrm{R}$ software ( $\mathrm{R}$ Development Core Team 2012).

Almost all studies used in the meta-analysis were conducted in coniferous forest. However, the distinction between coniferous, mixed and deciduous forest becomes arbitrary because foresters often cut down one type of forest and plant different one at the same site (e.g., Pedersen et al. 2010). Instead, we run two models: (1) including only data points from coniferous stands and (2) including data points from coniferous, deciduous and mixed stands. The results of both models were almost identical, and thus, we reported results of the more inclusive model. However, since majority of the studies were conducted in coniferous forest, our results are probably more representative of the responses of small mammals to clear-cutting in coniferous than in deciduous forests.

\section{Results}

Twenty studies met our criteria (see Table 1 for the list of studies used in the meta-analysis). They were published between 1959 and 2013. Twelve of them were conducted in boreal forests (bringing 61 data points, i.e., species $\times$ clear-cut combinations) and eight in temperate forests (95 data points). Out of the 156 data points, 130 were from coniferous stands, 18 were from mixed stands and 8 were from deciduous stands. The data were sufficient to quantify changes in abundance for nine small mammal species: the striped field mouse (Apodemus agrarius), the yellow-necked mouse (Apodemus flavicollis), the wood mouse (Apodemus sylvaticus), the field vole (Microtus agrestis), the common vole (Microtus arvalis), the bank vole (Myodes glareolus), the Eurasian harvest mouse (Micromys minutus), the common shrew (S. araneus) and the Eurasian pygmy shrew (Sorex minutus). The rest of reported small mammal species were reviewed only qualitatively in Discussion. That includes the following species: the gray-sided vole (Myodes rufucanus), the Siberian flying squirrel (Pteromys volans), the Eurasian red squirrel (Sciurus vulgaris) and the hazel dormouse (Muscardinus avellanarius).

The striped field mouse increased on clear-cuts in temperate forests of Europe $\left(t_{15,141}=2.42, P=0.02\right.$ no studies in boreal forest; Fig. 1). The yellow-necked mouse demonstrated marginally significant increase in response to clear-cutting in temperate forests $\left(t_{15,141}=1.76\right.$, $P=0.08)$ and significant decrease in boreal forests $\left(t_{15,141}=-2.14, \quad P=0.03\right)$. The response differed between the regions $\left(t_{15,141}=-2.68, P=0.008\right)$. In the case of the wood mouse, there was a marginally significant positive response to clear-cutting in temperate forests 
Table 1 Studies used in the meta-analysis on the influence of clear-cutting on small mammal abundance

\begin{tabular}{|c|c|c|c|c|}
\hline Reference & $\begin{array}{l}\text { Study location } \\
\text { (vegetation zone) }\end{array}$ & Forest type (dominant tree species) & $\begin{array}{l}\text { Age of } \\
\text { clear-cuts } \\
\text { (years) }\end{array}$ & Small mammal species \\
\hline Banach et al. 1979 & Poland (temperate) & Coniferous (Pinus sylvestris) & $0.5-15$ & A. sylvaticus, $M$. glareolus \\
\hline Bryja et al. 2002 & $\begin{array}{l}\text { Czech Republic } \\
\text { (temperate) }\end{array}$ & Coniferous (Picea abies) & $0-12$ & $\begin{array}{l}\text { A. flavicollis, } M . \text { agrestis, } M \text {. arvalis, } \\
\text { M. glareolus, } S \text {. araneus, } S \text {. minutus }\end{array}$ \\
\hline Čepelka et al. 2011 & $\begin{array}{l}\text { Czech Republic } \\
\text { (temperate) }\end{array}$ & $\begin{array}{l}\text { Coniferous (Picea abies) } \\
\text { Mixed (Fagus sylvatica and } \\
\text { Abies alba) }\end{array}$ & $\begin{array}{l}10 \\
1-13\end{array}$ & $\begin{array}{l}\text { A. flavicollis, M. agrestis, M. glareolus, } \\
\text { S. araneus }\end{array}$ \\
\hline Charles 1981 & $\begin{array}{r}\text { Great Britain } \\
\text { (temperate) }\end{array}$ & Coniferous (Pinus sylvestris) & $3-10$ & M. agrestis \\
\hline Ecke et al. 2002 & Sweden (boreal) & $\begin{array}{l}\text { Coniferous (Pinus sylvestris or } \\
\text { Picea abies) }\end{array}$ & $0-20$ & M. glareolus \\
\hline Gorini et al. 2011 & Norway (boreal) & $\begin{array}{l}\text { Coniferous (Pinus sylvestris or } \\
\text { Picea abies) }\end{array}$ & $5-10$ & M. glareolus \\
\hline Grodziński 1959 & Poland (temperate) & Coniferous (Picea abies) & $6-13$ & $\begin{array}{l}\text { A. agrarius, } \text { A. flavicollis, } \text { A. sylvaticus, } \\
\text { M. arvalis, M. glareolus, S. araneus }\end{array}$ \\
\hline $\begin{array}{l}\text { Hanski and Kaikusalo } \\
1989\end{array}$ & Finland (boreal) & Coniferous (Picea abies) & $1-5$ & Clear-cut: $S$. araneus, $S$. minutus \\
\hline Hansson 1974 & Sweden (boreal) & Coniferous (Picea abies) & $3-8$ & $\begin{array}{l}\text { A. flavicollis, A. sylvaticus, } \text { M. agrestis, } \\
\text { M. glareolus, S. araneus, S. minutus }\end{array}$ \\
\hline Hansson 1978 & Sweden (boreal) & Coniferous (Picea abies) & $0-5$ & $\begin{array}{l}\text { A. flavicollis, A. sylvaticus, M. agrestis, } \\
\text { M. glareolu, S. araneus }\end{array}$ \\
\hline Hansson 1992a & Sweden (boreal) & $\begin{array}{l}\text { Coniferous (Picea abies) } \\
\text { Deciduous (Fagus sylvatica) }\end{array}$ & $\begin{array}{l}\text { Unknown } \\
\text { Unknown }\end{array}$ & $\begin{array}{l}\text { A. flavicollis, A. sylvaticus, } \text { M. agrestis, } \\
\text { M. glareolus, S. araneus, S. minutus }\end{array}$ \\
\hline Hansson 1994 & Sweden (boreal) & $\begin{array}{l}\text { Coniferous (Pinus sylvestirs and } \\
\text { Picea abies) }\end{array}$ & $3-14$ & M. agrestis, $M$. glareolus, $S$. araneus \\
\hline Henttonen et al. 1977 & Finland (boreal) & $\begin{array}{l}\text { Coniferous (Pinus sylvestirs or } \\
\text { Picea abies) }\end{array}$ & Up to 10 & M. agrestis, $M$. glareolus \\
\hline Horváth et al. 2005 & Hungary (temperate) & Deciduous (Alnus spp.) & $3-4$ & $\begin{array}{l}\text { A. agrarius, A. flavicollis, M. glareolus, } \\
\text { S. araneus }\end{array}$ \\
\hline Jensen 1984 & Denmark (temperate) & $\begin{array}{l}\text { Coniferous (Picea sitchensis or } \\
\text { Abies grandis) }\end{array}$ & 10 & A. flavicollis, M. agrestis, M. glareolus \\
\hline Panzacchi et al. 2010 & Norway (boreal) & $\begin{array}{l}\text { Coniferous (Pinus sylvestirs or } \\
\text { Picea abies) }\end{array}$ & $0-5$ & $\begin{array}{l}\text { A. sylvaticus, M. agrestis, M. glareolus, } \\
\text { S. araneus }\end{array}$ \\
\hline Savola et al. 2013 & Finland (boreal) & $\begin{array}{l}\text { Coniferous (Pinus sylvestirs or } \\
\text { Picea abies) }\end{array}$ & $3-15$ & M. agrestis, $M$. glareolus, $S$. araneus \\
\hline Sidorovich et al. 2008 & Belarus (temperate) & $\begin{array}{l}\text { Coniferous (Pinus sylvestirs or } \\
\text { Picea abies) }\end{array}$ & $1-12$ & $\begin{array}{l}\text { A. agrarius, } \text { A. flavicollis, } \text { A. sylvaticus, } \\
\text { M. minutus, M. agrestis, } \text { M. arvalis, } \\
\text { M. glareolus, S. araneus, S. minutus }\end{array}$ \\
\hline Sundell et al. 2012 & Finland (boreal) & Coniferous (Picea abies) & 5 & M. agrestis, $M$. glareolus, $S$. araneus \\
\hline Wołk and Wołk 1982 & Poland (temperate) & $\begin{array}{l}\text { Coniferous (Pinus sylvestirs or } \\
\text { Picea abies) }\end{array}$ & $1-19$ & $\begin{array}{l}\text { A. flavicollis, M. glareolus, S. araneus, } \\
\text { S. minutus }\end{array}$ \\
\hline
\end{tabular}

$\left(t_{15,141}=1.81, P=0.07\right)$, whereas the response in boreal forest was not significant $\left(t_{15,141}=1.18, P=0.24\right)$. The field vole strongly increased on clear-cuts both in temperate forests $\left(t_{15,141}=4.21, P<0.0001\right)$ and boreal forests $\left(t_{15,141}=6.49, P<0.0001\right)$. The same was true for the common vole in temperate forests $\left(t_{15,141}=2.32\right.$, $P=0.02$; no studies in boreal forest). The abundance of bank voles showed no response to clear-cutting (temperate forests: $\quad t_{15,141}=-1.04, \quad P=0.30$; boreal forests: $\left.t_{15,141}=-0.002, P=0.99\right)$. The Eurasian harvest mouse increased in abundance on clear-cuts in temperate forests ( $t_{15,141}=3.01, P=0.003$; no studies in boreal forest $)$. The common shrew increased in response to clear-cut in temperate forests $\left(t_{15,141}=2.50, P=0.014\right)$ but not in boreal forests $\left(t_{15,141}=1.28, P=0.20\right)$. The Eurasian pygmy shrew showed no response to clear-cutting (temperate forests: $t_{15,141}=0.14, \quad P=0.89$; boreal forests: $\left.t_{15,141}=1.10, P=0.27\right)$. 


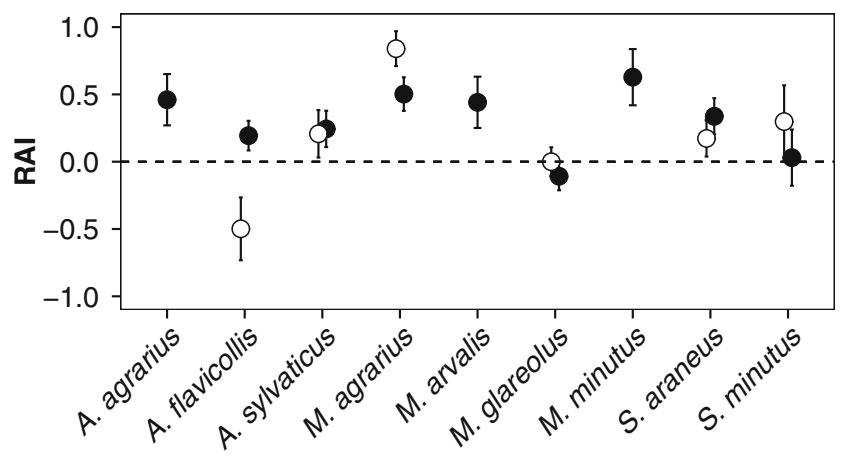

Fig. 1 Relative abundance indexes (RAI) of nine small mammal species in temperate (filled circles) and boreal forests (open circles) of Europe. RAI indicates relative differences in abundance of a given species between clear-cuts and unharvested forests. RAI might vary from -1 (species present only in unharvested forest) to 1 (species present only on clear-cuts). Whiskers indicate standard errors

\section{Discussion}

Responses of small mammals to clear-cutting: a metaanalysis

Our meta-analysis demonstrated a positive influence of clear-cutting on the abundance of most analyzed small mammals. In general, the responses to logging were similar in forests of temperate and boreal vegetation zones. The only species that reacted differently to clear-cutting in these two regions was the yellow-necked mouse, which tended to increase in clear-cuts in temperate zone, but declined in logged boreal forests. The only two species that did not show any change in abundance in response to clearcutting were bank voles and Eurasian pygmy shrews. The abundance of the rest of the analyzed species increased in clear-cuts to various extends in at least one of the analyzed regions. This result is in line with studies on the effects of clear-cutting on small mammals in North America (Zwolak 2009). Similar as in Europe, many North American small mammal species reach higher densities in harvested than in undisturbed forest. However, while our results suggest that the abundance of bank voles does not change after logging, in North America the red-backed vole (Myodes gapperi) strongly decreases in abundance on clear-cuts (Zwolak 2009). This difference is interesting because both Myodes species are considered forest specialists (Hansson 1996; Pearce and Venier 2005). The decrease in red-backed voles on clear-cuts could be the result of the strong association of this species with downed wood. As has been recently demonstrated, red-backed voles can be maintained on clear-cuts by providing sufficient amount of coarse woody debris (Sullivan et al. 2011, 2012). It has also been proposed that bank voles are more generalist in food habits than red-backed voles (Gliwicz and Glowacka 2000), and thus, they may be better adapted for colonizing disturbed areas like clear-cuts.

The positive response of most studied mammal species to clear-cuts could be attributed to an increase in forb and grass cover in the harvested areas. Lack of competition with trees in conjunction with better light conditions allows grass and herbs to quickly colonize disturbed areas (Peterken 2008). Abundance and species richness of vascular plants increases on clear-cuts compared to unmanaged stands (Keenan and Kimmins 1993; Paillet et al. 2010), providing small mammals with improved antipredatory cover and enhanced food resources. However, we also note that in the majority of analyzed studies, the reference sites consisted of managed, even-aged coniferous stands, which typically have poorly developed understory and low levels of coarse woody debris. In such situations, clear-cutting might greatly increase the structural complexity of habitats.

The increases in abundance after clear-cutting were most pronounced in species that prefer habitats dominated by graminoids. For example, the striped field mouse is positively influenced by the percentage of grassland in the landscape (Fischer et al. 2011) and reaches highest densities in afforestations and rural habitats (Szacki and Liro 1991). The same is true for the Eurasian harvest mouse, a species that prefers habitats with abundant vegetation cover (Churchfield et al. 1997a; Harris 2008). Strong positive response of the common and the field vole to clear-cutting is also not surprising and most likely results from the strong association of these two species with meadow habitats (Miklos and Ziak 2002; Borowski 2003). Similarly, the slight increase in the abundance of the wood mouse on clear-cuts can be attributed to the association of this species with grassy microhabitats: the wood mouse prefers meadows and windbreaks over closed-canopy habitats of forests (Hoffmeyer 1973; Churchfield et al. 1997a; Heroldová et al. 2007). It is associated with dense, tall vegetation cover and fallen logs (Marsh and Harris 2000). These habitat structures provide shelter and are available in early successional habitats like overgrown clear-cuts. Since distribution of the wood mouse on the stand scale is also correlated with the number of seedbearing herb and grass species (Angelstam et al. 1987), stronger positive response of the wood mouse in temperate than in boreal forests can be attributed to higher productivity of temperate than boreal habitats. Growing season in the temperate zone is almost two times longer than in the boreal zone, with both precipitation and temperature considerably higher in the temperate zone (Malhi et al. 2002). Therefore, the development of suitable, productive habitat is much faster, and most probably occurs more often after clear-cuts in temperate than in boreal zone.

The same explanation can be applied to the different response of the yellow-necked mouse to clear-cutting in 
boreal and temperate zones. This species is more strongly associated with forest habitats than the wood mouse (Montgomery 2008), although both grassland and forest habitats are considered suitable for this species (Hoffmeyer 1973). Therefore, the decline in abundance after clearcutting in boreal zone can be attributed to more permanent loss of habitat in boreal forests: while in the temperate zone, forest can be replaced with equally suitable grassland, in the boreal zone this process is slower and less likely to occur. Moreover, in boreal forests, tree seeds that are lost after clear-cutting may represent more important food source for the yellow-necked mouse then in relatively food-rich temperate forests. However, we did not find a relationship between RAI and age of clear-cut in boreal or temperate forest (unpublished analyses). Such association would be expected if habitat productivity played a role in described differences in species responses. One can expect that potential differences in abundance between clear-cuts and unharvested forest would diminish with time since disturbance and in more productive temperate habitats this process should occur faster. Nevertheless, the absence of relationship with time most likely reflects lack of power caused by small sample size or is related to the relatively narrow time window of analyzed responses (up to 20 years after disturbance). It is reasonable to assume that in the long term, the effects of disturbance on species abundance will taper off and finally disappear as was the case in North America (Zwolak 2009).

Both analyzed species of shrews are considered habitat generalists (Churchfield et al. 1997a), but the Eurasian pygmy shrew has wider niche breadth (Rychlik 2000) and is less dependent on habitat productivity than the common shrew (Hanski and Kaikusalo 1989; Churchfield et al. 1997b). Therefore, lack of response of the Eurasian pygmy shrew to habitat change in both zones may be attributed to opportunistic traits of this species. On the other hand, increase in the common shrew after logging in the temperate region could be associated with the increase in plant cover on clear-cuts, which provides shelter from predators. Birds of prey are the most important predators of shrews (Korpimäki and Norrdahl 1989), and the common shrew is preferred as prey over the smaller Eurasian pygmy shrew (Korpimäki and Norrdahl 1989). Hence, the common shrew could benefit more from the increased availability of cover on clear-cuts than the Eurasian pygmy shrew.

Another reason for the observed differences in shrews' response to clear-cutting could lie in their differing moisture requirements. The Eurasian pygmy shrew is more strongly associated with wet habitats than the common shrew (Rychlik 2000). Therefore, clear-cuts, which are generally drier than closed forest (Hansson 1992b), could be less suitable for $S$. minutus than for $S$. araneus.

Influence of forest management practices on small mammal species: a review

The meta-analysis was necessarily limited to the most widespread and common species of small mammals. Such species could be expected to have wide ecological tolerance and to be less affected by clear-cutting. Are the reactions of commonly studied small mammals representative of all small mammal species? The qualitative review provided below suggests that the effects of forest harvest on more specialized small mammal species (summarized in Table 2) are more varied than the generally positive effects on the most common small mammals.

Gray-sided vole

A long-term decline in numbers of the gray-sided vole observed in Fennoscandia is a subject of a wide debate (Hörnfeldt 2004; Christensen et al. 2008; Ims et al. 2008; Ecke et al. 2010). It is possible that the decline is caused by the global warming and thus warmer winters, affecting not only the gray-sided vole, but also Microtus species (Hörnfeldt 2004; Bierman et al. 2006; Ims et al. 2008). Increased temperatures in winter negatively affect the

Table 2 Main threats resulting from forest harvest posed to gray-sided vole (M. rufucanus), Siberian flying squirrel (P. volans), red squirrel (S. vulgaris) and hazel dormouse (M. avellanarius)

\begin{tabular}{llc}
\hline Species & Threat & Threat level \\
\hline Gray-sided vole & $\begin{array}{c}\text { Fragmentation (Christensen and Hörnfeldt 2006; } \\
\text { Christensen et al. 2008; Ecke et al. 2010). }\end{array}$ & $\begin{array}{c}\text { Moderate: forest harvest contributes to population } \\
\text { decline caused primarily by climate change. }\end{array}$ \\
Siberian flying squirrel & $\begin{array}{c}\text { Fragmentation (Mönkkönen et al. 1997), habitat loss } \\
\text { (Lampila et al. 2009; Santangeli et al. 2013b), } \\
\text { change in tree species composition (Reunanen et al. 2001). } \\
\text { Hed squirrel }\end{array}$ & $\begin{array}{c}\text { Severe: forest harvest is considered the main cause } \\
\text { of population decline. }\end{array}$ \\
Hazitat loss (Mortelliti et al. 2011). & $\begin{array}{c}\text { Minor: remain viable in fragmented landscapes but } \\
\text { rely on mature trees for food. }\end{array}$ \\
& Fragmentation (Bright and Morris 2008; Mortelliti et al. 2011). & $\begin{array}{c}\text { Moderate: prone to isolation in forest fragments, but } \\
\text { extensively use mid-successional clear-cuts. }\end{array}$ \\
\hline
\end{tabular}


depth of snow cover and the occurrence of subnivean space, both of which provide voles with protection against predators and adverse climatic conditions (Kausrud et al. 2008). In addition, more frequent melting-freezing events and winter rains encapsulate the vegetation in ice and decrease the availability of winter food for voles (Hansen et al. 2013). Forest harvest acts as a contributing factor, acting through habitat destruction and fragmentation. Occurrence of the gray-sided vole at the landscape level depends on the availability of high-quality, large patches of coniferous forests with low degree of fragmentation (Ecke et al. 2010). Clear-cuts seem to be avoided by C. rufucanus (Christensen and Hörnfeldt 2006), which suggests that increased amount of clear-cuts can make the dispersal of this species difficult and hence confine it to large forest patches (Christensen et al. 2008). As the long-term decline takes place also in areas where forestry is absent, the changes in landscape due to forest management could not be treated as the main cause of the decline (Ecke et al. 2010). However, while populations of the gray-sided vole in remote mountain areas have a chance to rebuild under favorable weather conditions, they will most likely not have this opportunity in fragmented lowland landscapes (Ecke et al. 2010).

\section{Siberian flying squirrel}

Siberian flying squirrel is an arboreal rodent that underwent severe decline in numbers in Europe and was even recognized regionally extinct in Finland (Hokkanen et al. 1982). Since then, the flying squirrel became a focal species in sustainable forest management in Finland and its persistence in managed forests is considered vital. Recently, it has been suggested that the flying squirrel could serve as an umbrella species for organisms depending on dead wood and old-growth forests (Hurme et al. 2008). Large-scale habitat changes due to modern forestry are suggested as the main cause of its decline (Hokkanen et al. 1982; Selonen et al. 2001; Reunanen et al. 2002b). The occurrence of this species is positively related to the cover of mature spruce forest with deciduous mixture, mainly aspen Populus tremula, birch Betula spp. and alder Alnus incana (Hanski 1998; Selonen et al. 2001; Reunanen et al. 2002b; Hurme et al. 2005; Hurme et al. 2007; Santangeli et al. 2013a). Old trees provide cavities for shelter or roosting, and deciduous trees are the main source of food as the flying squirrel forage on their leaves in summer and on catkins of alder and birch in winter (Hanski et al. 2000). Unfortunately, spruce trees were often replaced with pines in commercial forests, and the deciduous component of forest has been reduced or eliminated due to its low economic value (Reunanen et al. 2002a). Moreover, deciduous forest patches in boreal zone disappear during natural forest succession if not maintained by recurrent disturbances (Pickett 1985). Therefore, maintaining the deciduous mixture, particularly in spruce-dominated forest, should be of the primary importance in conservation policy of that species (Reunanen et al. 2001). In addition, the amount of mature sprucedominated forest area in the landscape should not drop below 12-16\% (Reunanen et al. 2004). The connectivity of suitable forest patches was also recognized as an important landscape feature (Reunanen et al. 2001; Reunanen et al. 2002c). Habitat fragmentation, the proportion of pine trees within the forest patch and open habitats such as clear-cuts negatively influence the habitat suitability for flying squirrels (Reunanen et al. 2002b; Mönkkönen et al. 2006; Santangeli et al. 2013a). On the stand scale, clearcutting decreases survival and population growth of flying squirrels (Lampila et al. 2009) and causes strong reduction in site occupancy (Santangeli et al. 2013b). Thus, forest management practices that are changing landscape prosperities, species composition of forest stands and clearcutting in particular are most probably the main threat for Siberian flying squirrels populations.

\section{Eurasian red squirrel}

The Eurasian red squirrel is strongly declining in Great Britain, and this decline has been linked to the displacement by the introduced gray squirrel (Sciurus carolinensis). Because there are some established populations of gray squirrels in Italy that in nearest future may spread over continental Europe the problem is not limited to British Isles (Bertolino et al. 2008). Moderately intense forest harvest is not considered to be a threat because populations of red squirrels often remain viable in fragmented landscapes (Andrén and Delin 1994; Delin and Andrén 1999; Verbeylen et al. 2003). Red squirrels are able to travel relatively long distances on open ground, thus are not as strongly affected by fragmentation as are other arboreal species (Wauters et al. 2010; Mortelliti et al. 2011). However, the amount of forest cover in the landscape is an important factor related to squirrels' presence (Mortelliti et al. 2011) and red squirrels avoid clear-cuts (Hansson 1994). Indirect evidence (changes in the diet of avian predators) suggests that red squirrels are declining in numbers in Fennoscandia where gray squirrels do not occur (Selonen et al. 2010). This decline might be caused by forest harvest and resulting habitat loss (Selonen et al. 2010). Red squirrels strongly rely on tree cones for food; therefore, young stands created by large-scale clear-cutting cannot support populations of squirrels until trees mature and produce seeds (Lurz et al. 2003).

On the other hand, forest management can be used to ensure viability of the red squirrel populations. Gray squirrels gain competitive advantage over red squirrels in 
conifer forests with oaks mixture (Lurz et al. 1995), but have lower survival in pure conifer stands (Kenward and Holm 1993; Kenward et al. 1998). Therefore, not planting oak species in large pine patches has been proposed as a part of conservation policy for red squirrels (Lurz et al. 2003).

\section{Hazel dormouse}

Hazel dormouse is red-listed in many European countries (Juškaitis 2007). As a strictly arboreal rodent, it is particularly vulnerable to habitat fragmentation and loss of patch connectivity (Bright and Morris 2008; Mortelliti et al. 2011). Although this species is able to move through open field when forced to do so (Bright 1998; Mortelliti et al. 2012), enhancing connectivity of patches in landscape by hedgerow planting greatly increases the probability of occurrence of hazel dormouse (Mortelliti et al. 2011). Moreover, this species lives in unusually low densities compared to other rodents (Bright and Morris 2008). Therefore, small isolated patches maintain low numbers of individuals that can easily go extinct due to demographic stochasticity (Bright and Morris 2008). On the other hand, clear-cutting per se is not a serious threat for the hazel dormouse as the decrease in abundance after this management practice is ephemeral and clear-cuts are usually recolonized within 5 years after disturbance (Juškaitis 2008; Troutet et al. 2012). Mid-successional sites with structurally heterogeneous young shrubs are known as the most suitable habitats for this species (Berg 1996). Such habitats are often found in young clear-cuts (Berg 1996). Thus, it appears that small-scale clear-cutting is does not pose a danger to this species. However, large-scale harvesting (thinning or clear-cuts) resulting in fragmentation and isolation of forest patches or destruction of winter hibernation nests might be detrimental for the hazel dormouse (Trout et al. 2012).

\section{Management implications}

Because species differ in their responses to forest harvest, there is no one-size-fits-all management solution. However, harvesting methods that produce less intense disturbances, such as removing single trees or small groups of trees, might be preferable over stand-replacing harvest when the goal is to minimize negative effects on wildlife. In addition, because of the importance of unharvested refugia, sometimes it might be better to conduct small-scale clearcutting than large-scale lower-intensity disturbance such as thinning (Trout et al. 2012). Forest harvest that results in changed species composition of stands, particularly when the endpoint are large-scale monocultures, is more likely to be detrimental to small mammals than harvest that does not result in tree species conversion (Pedersen et al. 2010). Leaving more coarse woody debris in harvested stand is highly recommended and has been recognized as a crucial practice for maintaining populations of small mammals and other wildlife (Siitonen 2001). Finally, longer harvest rotations would result in higher proportion of old forest, which ensures food resources for animals dependent on cones and fruits produced by mature trees.

Many of these recommendations are common sense solutions, and their effectiveness in specific situations should be validated with research (Simberloff 1999). In particular, studies on responses of European small mammals to methods of forest harvest other than clearcutting are rare. Furthermore, studies on species that are rare or ecologically specialized are particularly needed because such species are potentially threatened by forest harvest.

\section{Conclusions}

The results of our meta-analysis and the literature review suggest that small mammal vulnerability to forest management is species-specific. Commonly studied species included in the meta-analysis tended to increase in abundance in clear-cuts, and thus, this form of forest harvest is unlikely to pose a threat to widespread small mammal species. Open areas created by clear-cutting create suitable habitats for these species, and it is unlikely that resulting forest fragmentation will harm their populations. All of them are ground-dwelling species that take advantage of increased vegetation cover on clear-cuts. On the other hand, arboreal rodents like the Siberian flying squirrel, the Eurasian red squirrel and the hazel dormouse are more affected by forest discontinuity and therefore might be threatened by forest harvest, although to a different extent. This is not surprising since these species rely on the threedimensional space created by tree and shrub branches that is destroyed by felling. Moreover, even-aged stands often created by forest management decrease the structural heterogeneity of the arboreal habitat. However, responsible forest management policy that takes into account speciesspecific habitat requirements could considerably reduce the negative impact of forest harvest on most small mammal species.

Acknowledgments We thank Małgorzata Rychlik for her invaluable help with obtaining articles. The work was done while both authors were supported by MNiSW Grant NN304391537 awarded to RZ.

Open Access This article is distributed under the terms of the Creative Commons Attribution License which permits any use, distribution, and reproduction in any medium, provided the original author(s) and the source are credited. 


\section{References}

Andrén H, Delin A (1994) Habitat selection in the Eurasian red squirrel, Sciurus vulgaris, in relation to forest fragmentation. Oikos 70:43-48

Angelstam P, Kuuluvainen T (2004) Boreal forest disturbance regimes, successional dynamics and landscape structures: a European perspective. Ecol Bull 51:117-136

Angelstam P, Hansson L, Pehrsson S (1987) Distribution borders of field mice Apodemus: the importance of seed abundance and landscape composition. Oikos 50:123-130

Arnqvist G, Wooster D (1995) Meta-analysis: synthesizing research findings in ecology and evolution. TREE 10:236-240

Banach A, Kozakiewicz A, Kozakiewicz M (1979) Tentative comparison of small mammal communities in a poor pine stand of various ages. B Acad Pol Sci Biol 1(2):43-48

Bengtsson J, Nilsson SG, Franc A, Menozz P (2000) Biodiversity, disturbances, ecosystem function and management of European forests. For Ecol Manag 132:39-50

Berg L (1996) Small-scale changes in the distribution of the dormouse Muscardinus avellanarius (Rodentia, Myoxidae) in relation to vegetation changes. Mammalia 60:211-216

Bertolino S, Lurz PW, Sanderson R, Rushton SP (2008) Predicting the spread of the American grey squirrel (Sciurus carolinensis) in Europe: a call for a co-ordinated European approach. Biol Conserv 141:2564-2575

Bierman SM, Fairbairn JP, Petty SJ, Elston DA, Tidhar D, Lambin X (2006) Changes over time in the spatiotemporal dynamics of cyclic populations of field voles (Microtus agrestis L.). Am Nat 167:583-590

Borowski Z (2003) Habitat selection and home range size of field volesMicrotus agrestis in Słowiński National Park, Poland. Acta Theriol 48:325-333

Bright PW (1998) Behaviour of specialist species in habitat corridors: arboreal dormice avoid corridor gaps. Anim Behav 56:1485-1490

Bright P, Morris P (2008) Why are dormice rare? A case study in conservation biology. Mamm Rev 26:157-187

Bryja J, Heroldová M, Zejda J (2002) Effects of deforestation on structure and diversity of small mammal communities in the Moravskoslezské Beskydy Mts (Czech Republic). Acta Theriol 47:295-306

Čepelka L, Suchomel J, Purchart L, Heraldová M (2011) Small mammal diversity in the Beskydy Mts. forest ecosystems subject to different forms of management. Beskydy 4:101-108

Charles WN (1981) Abundance of field voles (Microtus agrestis) in conifer plantations. In: Last FT, Gardiner AS (eds) Forest and woodland ecology: an account of research being done in ITE. NERC/Institute of Terrestrial Ecology, Cambridge, pp 135-137

Christensen P, Hörnfeldt B (2006) Habitat preferences of Clethrionomys rufocanus in boreal Sweden. Landsc Ecol 21:185-194

Christensen P, Ecke F, Sandström P, Nilsson M, Hörnfeldt B (2008) Can landscape properties predict occurrence of grey-sided voles? Popul Ecol 50:169-179

Churchfield S, Rychlik L (2006) Diets and coexistence in Neomys and Sorex shrews in Białowieża forest, eastern Poland. J Zool 269:381-390

Churchfield S, Hollier J, Brown V (1997a) Community structure and habitat use of small mammals in grasslands of different successional age. J Zool 242:519-530

Churchfield S, Sheftel B, Moraleva N, Shvarts E (1997b) Habitat occurrence and prey distribution of a multi-species community of shrews in the Siberian taiga. J Zool 241:55-71

Delin AE, Andrén H (1999) Effects of habitat fragmentation on Eurasian red squirrel (Sciurus vulgaris) in a forest landscape. Landsc Ecol 14:67-72 den Ouden J, Jansen PA, Smit R (2005) Jays, mice and oaks: predation and dispersal of Quercusrobur and Q. petraea in North-western Europe. In: Forget PM et al (eds) Seed fate: predation, dispersal and seedling establishment. CAB International, UK, pp 223-239

Drożdż A (1966) Food habits and food supply of rodents in the beech forest. Acta Theriol 11:363-384

Ecke F, Löfgren O, Sörlin D (2002) Population dynamics of small mammals in relation to forest age and structural habitat factors in northern Sweden. J Appl Ecol 39:781-792

Ecke F, Christensen P, Rentz R, Nilsson M, Sandström P, Hörnfeldt B (2010) Landscape structure and the long-term decline of cyclic grey-sided voles in Fennoscandia. Landsc Ecol 25:551-560

Egger M, Smith GD, Schneider M, Minder C (1997) Bias in metaanalysis detected by a simple, graphical test. BMJ 315:629-634

Englund G, Sarnelle O, Cooper SD (1999) The importance of dataselection criteria: meta-analysis of stream predation experiments. Ecology 80:1132-1141

Fernandez-Duque E, Valeggia C (1994) Meta-analysis: a valuable tool in conservation research. Conserv Biol 8:555-561

Fischer C, Thies C, Tscharntke $T$ (2011) Small mammals in agricultural landscapes: opposing responses to farming practices and landscape complexity. Biol Conserv 144:1130-1136

Fisher JT, Wilkinson L (2005) The response of mammals to forest fire and timber harvest in the North American boreal forest. Mamm Rev 35:51-81

García D, Obeso JR, Martínez I (2005) Rodent seed predation promotes differential recruitment among bird-dispersed trees in temperate secondary forests. Oecologia 144:435-446

Gliwicz J, Glowacka B (2000) Differential responses of Clethrionomys species to forest disturbance in Europe and North America. Can J Zool 78:1340-1348

Gómez JM, García D, Zamora R (2003) Impact of vertebrate acornand seedling-predators on a Mediterranean Quercus pyrenaica forest. For Ecol Manag 180:125-134

Gorini L, Linnell JDC, Boitani L, Hauptmann U, Odden M, Wegge P, Nilsen EB (2011) Guild composition and habitat use of voles in 2 forest landscapes in south-eastern Norway. Integr Zool 6:299-310

Grodziński W (1959) The succession of small mammal communities on an overgrown clearing and landslip mountain in the Beskid Sredni (Western Carpathians). Ekol Pol 7:83-143

Gurevitch J, Hedges LV (1999) Statistical issues in ecological metaanalyses. Ecology 80:1142-1149

Gurevitch J, Morrow LL, Wallace A, Walsh JS (1992) A meta-analysis of competition in field experiments. Am Nat 140:539-572

Hannah L, Carr JL, Lankerani A (1995) Human disturbance and natural habitat: a biome level analysis of a global data set. Biodivers Conserv 4:128-155

Hansen BB, Grøtan V, Aanes R, Sæther BE, Stien A, Fuglei E, Ims RA, Yoccoz NG, Pedersen $\AA \varnothing$ (2013) Climate events synchronize the dynamics of a resident vertebrate community in the high Arctic. Science 339:313-315

Hanski IK (1998) Home ranges and habitat use in the declining flying squirrel Pteromys volans in managed forests. Wildl Biol 4:33-46

Hanski I, Kaikusalo A (1989) Distribution and habitat selection of shrews in Finland. Ann Zool Fenn 26:339-348

Hanski IK, Stevens PC, Ihalempiä P, Selonen V (2000) Home-range size, movements, and nest-site use in the Siberian flying squirrel, Pteromys volans. J Mamm 81:798-809

Hansson L (1974) Small mammal productivity and consumption in spruce forest and reforestation in South Sweden. Oikos 25:153-156

Hansson L (1978) Small mammal abundance in relation to environmental variables in three Swedish forest phases. Studia Forestalia Suecica 147:1-40 
Hansson L (1992a) Landscape ecology of boreal forests. TREE 7:299-302

Hansson L (1992b) Small mammal communities on clearcuts in a latitudinal gradient. Acta Oecologica 13:687-699

Hansson L (1994) Vertebrate distributions relative to clear-cut edges in a boreal forest landscape. Landsc Ecol 9:105-115

Hansson L (1996) Habitat selection or habitat-dependent survival: on isodar theory for spatial dynamics of small mammals. Oikos 75:539-542

Harris S (2008) History, distribution, status and habitat requirements of the harvest mouse (Micromys minutus) in Britain. Mamm Rev 9:159-171

Henttonen H, Kaikusalo A, Tast J, Viitala J (1977) Interspecific competition between small rodents in subarctic and boreal ecosystems. Oikos 29:581-590

Heroldová M, Bryja J, Zejda J, Tkadlec E (2007) Structure and diversity of small mammal communities in agriculture landscape. Agric Ecosyst Environ 120:206-210

Heyman P, Vaheri A, Lundkvist Å, Avsic-Zupanc T (2009) Hantavirus infections in Europe: from virus carriers to a major publichealth problem. Expert Eev Anti-Infe 7:205-217

Hoffmeyer I (1973) Interaction and habitat selection in the mice Apodemus flavicollis and A. sylvaticus. Oikos 24:108-116

Hokkanen H, Törmälä T, Vuorinen H (1982) Decline of the flying squirrel Pteromys volans 1 . populations in Finland. Biol Conserv 23:273-284

Hörnfeldt B (2004) Long-term decline in numbers of cyclic voles in boreal Sweden: analysis and presentation of hypotheses. Oikos 107:376-392

Horváth G, Molnár D, Csonka G (2005) Population dynamics and spatial pattern of small mammals in protected forest and reforested area. Nat Som 7:191-207

Hurme E, Mönkkönen M, Nikula A, Nivala V, Reunanen P, Heikkinen T, Ukkola M (2005) Building and evaluating predictive occupancy models for the Siberian flying squirrel using forest planning data. For Ecol Manag 216:241-256

Hurme E, Reunanen P, Mönkkönen M, Nikula A, Nivala V, Oksanen J (2007) Local habitat patch pattern of the Siberian flying squirrel in a managed boreal forest landscape. Ecography 30:277-287

Hurme E, Mönkkönen M, Sippola AL, Ylinen H, Pentinsaari M (2008) Role of the Siberian flying squirrel as an umbrella species for biodiversity in northern boreal forests. Ecol Indic 8:246-255

Ims RA, Henden JA, Killengreen ST (2008) Collapsing population cycles. TREE 23:79-86

Jędrzejewska B, Jędrzejewski W (1998) Predation in vertebrate communities: the Bialowieza Primeval Forest as a case study. Springer, Berlin

Jensen T (1984) Habitat distribution, home range and movements of rodents in mature forest and reforestations. Acta Zool Fenn 171:305-307

Jones CG, Ostfeld RS, Richard MP, Schauber EM, Wolff JO (1998) Chain reactions linking acorns to gypsy moth outbreaks and Lyme disease risk. Science 279:1023-1026

Juškaitis R (2007) Peculiarities of habitats of the common dormouse, Muscardinus avellanarius, within its distributional range and in Lithuania: a review. Folia Zool 56:337-348

Juškaitis R (2008) Long-term common dormouse monitoring: effects of forest management on abundance. Biodivers Conserv 17:3559-3565

Kausrud KL, Mysterud A, Steen H, Vik JO, Østbye E, Cazelles B, Framstad E, Eikeset AM, Mysterud I, Solhøy T (2008) Linking climate change to lemming cycles. Nature 456:93-97

Keenan RJ, Kimmins J (1993) The ecological effects of clear-cutting. Environ Rev 1:121-144

Kenward R, Holm J (1993) On the replacement of the red squirrel in Britain. A phytotoxic explanation. Proc Roy Soc B-Biol Sci 251:187-194
Kenward R, Hodder K, Rose R, Walls C, Parish T, Holm J, Morris P, Walls S, Doyle F (1998) Comparative demography of red squirrels (Sciurus vulgaris) and grey squirrels (Sciurus carolinensis) in deciduous and conifer woodland. J Zool 244:7-21

Kirkland GL Jr (1990) Patterns of initial small mammal community change after clearcutting of temperate North American forests. Oikos 59:313-320

Korpimäki E, Norrdahl K (1989) Avian and mammalian predators of shrews in Europe: regional differences, between-year and seasonal variation, and mortality due to predation. Ann Zool Fenn 260:389-400

Kuuluvainen T (2009) Forest management and biodiversity conservation based on natural ecosystem dynamics in northern Europe: the complexity challenge. Ambio 38:309-315

Lampila S, Wistbacka R, Mäkelä A, Orell M (2009) Survival and population growth rate of the threatened siberian flying squirrel (Pteromys volans) in a fragmented forest landscape. Ecoscience 16:66-74

Lurz PW, Garson P, Rushton S (1995) The ecology of squirrels in spruce dominated plantations: implications for forest management. For Ecol Manag 79:79-90

Lurz PW, Geddes N, Lloyd A, Shirley M, Rushton S, Burlton B (2003) Planning a red squirrel conservation area: using a spatially explicit population dynamics model to predict the impact of felling and forest design plans. Forestry 76:95-108

Malhi Y, Baldocchi D, Jarvis P (2002) The carbon balance of tropical, temperate and boreal forests. Plant Cell Environ 22:715-740

Marsh A, Harris S (2000) Partitioning of woodland habitat resources by two sympatric species of Apodemus: lessons for the conservation of the yellow-necked mouse A. flavicollis in Britain. Biol Conserv 92:275-283

Miklos P, Ziak D (2002) Microhabitat selection by three small mammal species in oak-elm forest. Folia Zool 51:275-288

Mönkkönen M, Reunanen P, Nikula A, Inkeröinen J, Forsman J (1997) Landscape characteristics associated with the occurrence of the flying squirrel Pteromys volans in old-growth forests of northern Finland. Ecography 20:634-642

Montgomery W (2008) Studies on the distributions of Apodemus sylvaticus (L.) and A. flavicollis (Melchior) in Britain. Mamm Rev 8:177-184

Mortelliti A, Amori G, Capizzi D, Cervone C, Fagiani S, Pollini B, Boitani L (2011) Independent effects of habitat loss, habitat fragmentation and structural connectivity on the distribution of two arboreal rodents. J Appl Ecol 48:153-162

Mortelliti A, Santarelli L, Sozio G, Fagiani S, Boitani L (2012) Long distance field crossings by hazel dormice (Muscardinus avellanarius) in fragmented landscapes. Mamm Biol 78:309-312

Murtaugh PA (2002) Journal quality, effect size, and publication bias in meta-analysis. Ecology 83:1162-1166

Ostfeld RS, Manson RH, Canham CD (1997) Effects of rodents on survival of tree seeds and seedlings invading old fields. Ecology 78:1531-1542

Östlund L, Zackrisson O, Axelsson AL (1997) The history and transformation of a Scandinavian boreal forest landscape since the 19th century. Can J For Res 27:1198-1206

Paillet Y, Bergès L, Hjälten J, Ódor $\mathrm{P}$, Avon C, BernhardtRömermann M, Bijlsma RJAN, De Bruyn L, Fuhr M, Grandin U (2010) Biodiversity Differences between Managed and Unmanaged Forests: meta-Analysis of Species Richness in Europe. Conserv Biol 24:101-112

Panzacchi M, Linnell JDC, Melis C, Odden M, Odden J, Gorini L, Andersen R (2010) Effect of land-use on small mammal abundance and diversity in a forest-farmland mosaic landscape in south-eastern Norway. For Ecol Manag 259:1536-1545 
Pearce J, Venier L (2005) Small mammals as bioindicators of sustainable boreal forest management. For Ecol Manag 208:153-175

Pedersen AØ, Yoccoz NG, Ims RA, Sigurdsen T (2010) Effects on non-native spruce plantations on small mammal communities in subarctic birch forests. For Ecol Manag 260:331-338

Peterken GF (2008) Structural dynamics of forest stands and natural processes. In: Evans J (ed) The forests handbook, volume 1: an overview of forest science. Blackwell Science Ltd, Oxford

Pickett ST (1985) The ecology of natural disturbance and patch dynamics. Academic, London

Prieto-Benítez S, Méndez M (2011) Effects of land management on the abundance and richness of spiders (Araneae): a metaanalysis. Biol Conserv 144:683-691

Reunanen P, Mönkkönen M, Nikula A (2001) Managing boreal forest landscapes for flying squirrels. Conserv Biol 14:218-226

Reunanen P, Mönkkönen M, Nikula A (2002a) Habitat requirements of the Siberian flying squirrel in northern Finland: comparing field survey and remote sensing data. Ann Zool Fenn 39:7-20

Reunanen P, Nikula A, Mönkkönen M (2002b) Regional landscape patterns and distribution of the Siberian flying squirrel Pteromys volans in northern Finland. Wildl Biol 8:267-278

Reunanen P, Nikula A, Mönkkönen M, Hurme E, Nivala V (2002c) Predicting occupancy for the Siberian flying squirrel in oldgrowth forest patches. Ecol Appl 12:1188-1198

Reunanen P, Mönkkönen M, Nikula A, Hurme E, Nivala V (2004) Assessing landscape thresholds for the Siberian flying squirrel. Ecol Bull 51:277-286

Rychlik L (2000) Habitat preferences of four sympatric species of shrews. Acta Theriol 45:173-190

Santangeli A, Hanski IK, Mäkelä H (2013a) Integrating multi-source forest inventory and animal survey data to assess nationwide distribution and habitat correlates of the Siberian flying squirrel. Biol Conserv 157:31-38

Santangeli A, Wistbacka R, Hanski IK, Laaksonen T (2013b) Ineffective enforced legislation for nature conservation: a case study with Siberian flying squirrel and forestry in a boreal landscape. Biol Conserv 157:237-244

Savola S, Henttonen H, Lindén H (2013) Vole population dynamics during succession of a commercial forest in northern Finland. Ann Zool Fenn 50:79-88

Schickmann S, Urban A, Kräutler K, Nopp-Mayr U, Hackländer K (2012) The interrelationship of mycophagous small mammals and ectomycorrhizal fungi in primeval, disturbed and managed Central European mountainous forests. Oecologia 170:395-409

Selonen V, Hanski IK, Stevens PC (2001) Space use of the Siberian flying squirrel Ptevomys volans in fragmented forest landscapes. Ecography 24:588-600

Selonen V, Sulkava P, Sulkava R, Sulkava S, Korpimäki E (2010) Decline of flying and red squirrels in boreal forests revealed by long-term diet analyses of avian predators. Anim Conserv 13:579-585

Sidorovich VE, Solovej IA, Sidorovich AA, Rotenko II (2008) Effect of felling on the distribution of rodents and their predators in a transitional mixed forest. Pol J Ecol 56:309-321
Siitonen J (2001) Forest management, coarse woody debris and saproxylic organisms: Fennoscandian boreal forests as an example. Ecol Bull 49:11-41

Simberloff D (1999) The role of science in the preservation of forest biodiversity. For Ecol Manag 115:101-111

Simberloff D (2001) Management of boreal forest biodiversity-a view from the outside. Scand J For Res 16:105-118

Sullivan TP, Sullivan DS, Lindgren PM, Ransome DB, Bull JG, Ristea C (2011) Bioenergy or biodiversity? Woody debris structures and maintenance of red-backed voles on clearcuts. Biomass Bioenerg 35:4390-4398

Sullivan TP, Sullivan DS, Lindgren PM, Ransome DB (2012) If we build habitat, will they come? Woody debris structures and conservation of forest mammals. J Mamm 93:1456-1468

Sundell J, Church C, Ovaskainen (2012) Spatio-temporal patterns of habitat use in voles and shrews modified by density, season and predators. J Anim Ecol 81:747-755

Sutherland WJ, Pullin AS, Dolman PM, Knight TM (2004) The need for evidence-based conservation. TREE 19:305-308

Szacki J, Liro A (1991) Movements of small mammals in the heterogeneous landscape. Landsc Ecol 5:219-224

R Core Team (2012) R: a language and environmental for statistical computing. R Fundation for Statistical Coputing, Vienna, Austria. (http://www.R-project.org)

Trout R, Brooks S, Rudlin P, Neil J (2012) The effects of restoring a conifer Plantation on an Ancient Woodland Site (PAWS) in the UK on the habitat and local population of the Hazel Dormouse (Muscardinus avellanarius). Eur J Wildl Res 58:635-643

Vanderwel MC, Malcolm JAYR, Mills SC (2007) A Meta-Analysis of Bird Responses to Uniform Partial Harvesting across North America. Conserv Biol 21:1230-1240

Verbeylen G, De Bruyn L, Matthysen E (2003) Patch occupancy, population density and dynamics in a fragmented red squirrel Sciurusvulgaris population. Ecography 26:118-128

Wauters LA, Verbeylen G, Preatoni D, Martinoli A, Matthysen E (2010) Dispersal and habitat cuing of Eurasian red squirrels in fragmented habitats. Popul Ecol 52:527-536

Wołk E, Wołk K (1982) Responses of small mammals to the forest management in the Bialowieża Primeval Forest. Acta Theriol 27:45-59

Zuur AF, Ieno EN, Walker N, Saveliev AA, Smith GM (2009) Mixed effects models and extensions in ecology with R. Springer, New York

Zwolak R (2009) A meta-analysis of the effects of wildfire, clearcutting, and partial harvest on the abundance of North American small mammals. For Ecol Manag 258:539-545

Zwolak R, Crone EE (2012) Quantifying the outcome of plantgranivore interactions. Oikos 121:20-27

Zwolak R, Pearson DE, Ortega YK, Crone EE (2010) Fire and mice: seed predation moderates fire's influence on conifer recruitment. Ecology 91:1124-1131 